\title{
The Missing Linke? Restraint and Realignment in the German Left, 2005-2017
}

\author{
¿El eslabón perdido? Restricción y realineamiento \\ dentro de la izquierda alemana, 2005-2017
}

\author{
KNUT RODER \\ Sheffield Hallam University
}

\section{Cómo citar/Citation}

Roder, K. (2017). The Missing Linke? Restraint and Realignment int he German Left, 2005-2017. Revista Española de Ciencia Política, 45, 43-65. Doi: https://doi.org/10.21308/recp.45.02

\begin{abstract}
This article serves two purposes: Firstly, it aims to introduce the reader to the rich and diverse party environment of the German radical left party "Die Linke". Secondly, this paper is going to argue that the party's apparent lack of "office-seeking" at the national level is directly relat to the requirements of its immense diversity. The issue addressed focuses on one of the aspects of the failure of cooperation between the three parties on Germany's centre-left at the national level, and argues that besides the hesitancy of the SPD and Greens to embrace such an undertaking, Die Linke has not been ready to push for a left of centre cooperation either, due to an existential need of self-preservation and internal cohesion. This paper is based on an analysis of Die Linke's policy debates on the issue of the economic and euro-zone crises as an example to document the large number of competing and politically diverse factions within the party that must find common policy ground and be accommodated when reaching party-wide policy positions. While this tension can be overcome by agreeing on low common denominators to voice concerns and reject government policies in an opposition role, the role as a potential junior partner in a wider "centre-left" party coalition would require far more advanced agreements on wide-ranging policy compromises with the SPD and Greens; and this would be highly divisive and threaten Die Linke's inner-party cohesion. In response, Die Linke has continued to avoid committing to a strategy that would clearly advocate the formation of a national level "left-of-centre" party coalition to challenge the country's centre-right government.
\end{abstract}

Keywords: cohesion, cooperation, crisis, Germany, left, Die Linke, office-seeking, party politics, radicalism. 


\section{Resumen}

Este artículo tiene dos objetivos: en primer lugar, pretende introducir al lector en el rico y diverso ambiente del partido de la izquierda radical alemán Die Linke. En segundo lugar, este artículo argumentará que la aparente falta de orientación del partido a la "búsqueda de cargos públicos" a nivel nacional está directamente relacionada con los requisitos de su inmensa diversidad. El tema abordado se centra en uno de los aspectos del fracaso en la cooperación entre los tres partidos de centro-izquierda en Alemania a nivel nacional, y argumenta , además de la indecisión del SPD y de los Verdes para abrazar tal proyecto, Die Linke tampoco ha estado preparado para presionar en busca de una cooperación de izquierda, debido a una necesidad existencial de autopreservación y cohesión interna. Este artículo se basa en el análisis de los debates políticos de Die Linke sobre el tema de la crisis económica y de la eurozona como un ejemplo para documentar el gran número de facciones en competición y políticamente diversas dentro del partido, que tienen que encontrar una base política común y ser acomodadas cuando el partido adopta posiciones políticas. Aunque esta tensión puede superarse cuando se alcancen acuerdos para expresar inquietudes y rechazar las políticas gubernamentales en un papel de oposición, el papel de un posible socio menor en una coalición de partidos de centroizquierda más amplia requeriría acuerdos mucho más avanzados en compromisos sobre políticas de amplio alcance con el SPD y los Verdes, que serían altamente divisivos y amenazarían la cohesión interna de Die Linke. Como respuesta, Die Linke ha evitado comprometerse con una estrategia que claramente abogaría por la formación de una coalición de centro-izquierda a nivel nacional para desafiar al Gobierno de centroderecha estatal.

Palabras clave: cohesion, cooperation, crisis, Alemania, izquierda, Die Linke, consecución de cargos, política partidista, radicalismo.

\section{INTRODUCTION}

Die Linke, as one of the three left-wing parties represented in Germany's national parliament, holds the potential to be part of a wider "left-of-centre" party coalition that could challenge Germany's centre-right majority -electoral arithmetic permitting-. The country's other two well -established parties to the centre-left of the political spectrum are Germany's "Sozialdemokratische Partei Deutschlands" (SPD) and "Bündnis 90/Die Grünen" (Greens). Die Linke is one of the few radical left parties in Europe, compared to most fellow members in the European Parliament's "European United Left/Nordic Green Left" party group, that under certain circumstances could potentially play a part in the formation of a national level "left-of-centre" coalition government; something Die Linke only has experience in on the country's regional Länder level. This raises the question of why the party has failed to link up with the SPD and Greens and aim for cooperation at national level, so far.

One obvious reason for Die Linke's perceived lack of "office-seeking" is related to the attitude displayed by the SPD and Greens, which have publicly mostly ruled out the possibility of seeking a "left-of-centre" party cooperation with the more "radical" Die 
Linke, both for strategic electoral reasons as well as programmatic disagreements. In fact, the SPD leadership has repeatedly accused Die Linke of being "untrustworthy and irresponsible" in regard to the "parties" spending pledges" as well as "foreign and defence policies"; and it has described Die Linke as "unfit and unreliable" for any type of coalition arrangement (Stern, 2005; Höll, 2012; Tagesspiegel, 2016). This also partly explains why the SPD chose to join CDU/CSU-led conservative governments as a junior partner in 2005 (-2009) as well as 2013 (-2017), instead of seeking a "left-of-centre" alternative. Similarly, possible cooperation in the Bundestag between the Greens" and Die Linke's parliamentary party groups has been kept to a noticeable minimum (Der Spiegel, 2015a) (see also table 2). These attitudes have been expressed even in spite of the fact that the three parties on the left held a numerical majority of seats after the country's 2013 general election (as well as in 2005), which meant the parties potentially held the key to the establishment of a left-of-centre majority government alternative (see table 1).

As for the electoral and strategic prospects of Germany's 2017 general election, all three parties made attempts to explore ideas and find common ground for a future so-called Red-Red-Green (R2G) coalition at the national level (Gathmann, 2016). However, a lack of conviction for such a project clearly continued among all three in spite of the fact that this appeared to be the only way to unsettle a Merkel-led government. This situation is not unique to Germany, where parties on the "centre-left", mainly social democratic ones, have been hesitant to consider co-operating with parties located further to the radical left of the political spectrum in order to set up a "leftof-centre" coalition that could remove sitting conservative governments.

There currently appears to be a growing sense in the literature that the onset of the financial crisis and an increasingly critical discourse towards free market economics may have caused policy ideas from parties on the radical left to "appear to move from marginality to the mainstream" (March and Keith, 2016: 1) and gain traction with left parties located further towards the centre of the spectrum. There has also been a noticeable re-emergence of interest and an increase in the number of publications dealing with parties on the radical left. March and Keith (2016) have gone as far as categorising such publications into four sets: (1) works that aim to provide more conceptual clarity about the ideology of parties on the radical left; (2) publications that analyse the radical left's programmatic approaches towards Europe; (3) studies on radical left parties" involvement in government; and (4) publications that deal with the diverging electoral performances that radical left parties have experienced over recent years (March and Keith, 2016: 2). This article seeks to contribute to the growing body of works on radical parties by offering a case study on Die Linke's intellectual, programmatic and strategic responses to the crisis.

There are two key factors that can be held responsible for the lack of cooperation amongst Germany's parties on the centre-left. Firstly, the SPD and Green centre-left rival parties have consistently justified their dismissal of national-level co-operation with Die Linke by claiming that the party would be neither able, nor willing to compromise on key-controversial policies as well as being an untrustworthy coalition partner (Stern, 2005; Höll, 2012; Tagesspiegel, 2016). Secondly, but commonly overlooked, and the 
main focus of this article, there appears to be an inability or even refusal coming from within Die Linke to advocate national level coalition building with the SPD and Greens, contributing to the perception that the party may well be the "missing link" to any "leftof-centre" majority. This "vote-seeking" over "office-seeking" issue has also been noted by Paolo Chiocchetti, who described Die Linke in his extensive study of Western Europe's parties on the radical left, as a serious "electoral success story" that nevertheless "...failed to become a fully credible alternative to the established parties", hinting at the party's lack of political effectiveness due to lacking the ambition to fully engage with Germany's political system and aim for "office" (Chiocchetti, 2017: 81). The reason may well be, as argued by Amieke Bouma for the case of the party's policies on the crisis, Die Linke's struggle to reconcile internal divisions in the light of formulating a clear response and strategy to deal with the issue, something she blames on the party's historic variety of internal constituencies that continue to constrain the formulation of unified policy responses (Bouma, 2016: 149).

This then triggers the question of whether these divisions between the different constituencies within the party may be a key cause of Die Linke's inability to engage more willingly with the idea of aiming to become part of a wider left-of-centre coalition government. And arguably, this has taken place at a time when the financial crisis might have also acted as a source of inspiration to the party's constituencies by reinforcing commonly held key beliefs in the dysfunctionality of the neoliberal policy paradigm. This, in turn, could have been expected to bring together the different party tendencies in their quest for agreement and to formulate a coherent alternative policy agenda (Bouma, 2016, 146) and increase the willingness to engage more positively with other parties on the left. In either case, the analysis of Die Linke's engagement with the crisis serves as a helpful example to improve our understanding of the dynamics that have been at work when the party responded to policy challenges during that period.

In order to gain a better understanding of Die Linke's ability to formulate coherent policies, it is helpful to analyse the creation and make-up of Die Linke and its ability to "speak with one voice". Similarly, it is useful to recognise that the party unites a "broad house" and large variety of left and radical left political traditions that inevitably disagree over fundamental strategic and policy alignment. As an illustration, we will briefly look at the policy positions devised by Die Linke's component wings on the (euro) crisis.

The article starts by locating Die Linke within Germany's party-political system and identifies the large variety of actors that form the inner-party tendencies and make of the party such a "broad coalition of left wing ideology and thinking". Afterwards, these findings offer the context for locating and comparing the party actors" policy positions on the Euro-crisis, including an analysis of the parliamentary party wings" voting behaviour in the Bundestag. Finally, and as it is highlighted in the conclusion, this analysis shows the extent of fundamental policy disagreements within the party, culminating in a party-wide movement of restraint and realignment and leading to the distinct policy positions and attitudes that prevent Die Linke's from embracing "deeper cooperation" with the other parties on the "centre-left"; a challenge that appears even more pressing after the country's 2017 general election outcome. 


\section{DIE LINKE AND THE GERMAN PARTY SYSTEM}

Die Linke emerged in its current form in 2007, after a merger of the "Electoral Alternative for Employment and Social Justice" (Wahlalternative Arbeit und Soziale Gerechtigkei-WASG) that had been formed a couple of years before by disaffected social democrats and trade unions disillusioned with the sitting SPD-led "third way" government and its labour market reforms on the one hand, and the Partei des Demokratischen Sozialismus (Party of Democratic Socialism-PDS/Linkspartei) on the other hand. The PDS had been formed from the remnants of East Germany's Democratic Republic's (GDR) Socialist Unity Party (SED) which, despite having been represented in the Bundestag since unification, had not risen much beyond regional electoral success in the East and the status of a "left" representation of East Germans" interests after the 1990s unification.

The merger of both parties meant not only the blending of two distinct "left" traditions, but also that Die Linke was able to widen (more or less successfully) its electoral appeal nationwide and establish itself as a political party to the left of the SPD and Greens throughout Germany (Holmes and Roder, 2012: 97). This claim is underlined by the fact that the party has ideologically been far more critical and unaccommodating of the country's economic system by continuing to argue that "capitalism proves itself incapable of solving the most pressing problems of humanity" (Die Linke, 2013: 46). Similarly, when looking at the Die Linke's voting record in the Bundestag on issues related to the financial- and Euro crisis, the party has, on ideological grounds, consistently argued and voted against government initiatives. This has often placed Die Linke in stark contrast to the representatives of the other two parties from the centre-left, the SPD and Greens, which over time have been far more willing to engage with and support government policies on the crisis (see roll-call voting record on table 2).

TABLE 1 .

German election Results (in \% OF VOte) AND gOVernMENT COALitions, 2002-20I3

\begin{tabular}{cccccccc}
\hline $\begin{array}{c}\text { Election } \\
\text { Year }\end{array}$ & $\begin{array}{c}\text { Die } \\
\text { Linke }\end{array}$ & $\begin{array}{c}\text { Bündnis 90/ } \\
\text { Die Grünen }\end{array}$ & SPD & CDU/CSU & FDP & AfD & $\begin{array}{c}\text { Government } \\
\text { (coalition) }\end{array}$ \\
\hline 2002 & $4.0 \%$ & $8.6 \%$ & $38.5 \%$ & $38.5 \%$ & $7.4 \%$ & - & SPD / GRÜN \\
\hline 2005 & $8.7 \%$ & $8.1 \%$ & $34.2 \%$ & $35.2 \%$ & $9.8 \%$ & - & CDU / SPD \\
\hline 2009 & $11.9 \%$ & $10.7 \%$ & $23.0 \%$ & $33.8 \%$ & $14.6 \%$ & - & CDU / FDP \\
\hline 2013 & $8.2 \%$ & $8.4 \%$ & $25.7 \%$ & $41.5 \%$ & $4.8 \%$ & $4.7 \%$ & CDU / SPD \\
\hline 2017 & $9.2 \%$ & $8.9 \%$ & $20.5 \%$ & $32.9 \%$ & $10.7 \%$ & $12.6 \%$ & \\
\hline
\end{tabular}

Notes: Centre-left in bold. "Die Linke": 2005 electoral alliance "PDS. Linkspartei" \& "WSAG"; 2002 "Partei des Demokratischen Sozialismus" (below $5 \%$ representational threshold with only two direct constituency mandates). 


\section{ANALYSING AND UNDERSTANDING DIFFERING POLICY ATTITUDES AND DIFFERENTIATING DIE LINKE'S POLITICAL WINGS}

Before looking at Die Linke's debates over the financial and euro crisis, it is important to recognise that the party constitutes a broad coalition of left wing ideology and thinking that reaches well beyond the party politics of its predecessors, PDS/Linkspartei and WASG. While there may be plenty of common ground between the party's different wings when it comes to agreements over the understanding of the economic problems and their causes, these various tendencies within Die Linke can be easily differentiated, as rightly pointed out by Benjamin-Emmanuel Hoff (2014: 128135), according to their degree of fundamental opposition or willingness to engage with and believe in the ability to transform the status quo represented by the political system. Such an approach would also reach beyond the more traditional attempts to understand the party by differentiating its wings along domestic structural issue lines that reflect differences among party members and voters in the East and West of Germany, between former members of the PDS and WASG, or between reformers and traditionalists (ibid:: 124).

Another way to enhance the analysis of Die Linke could be to focus on the divisions regarding the party goals. While salience theorists typically focus on electoral success, parties may seek multiple goals that may or may not be mutually compatible, namely vote-seeking, office-seeking (in conjunction with policy-seeking) or cohesion-seeking (Steenbergen and Scott, 2004: 168). And while vote-seeking has certainly been a major goal, with the 2013 general election outcome meaning that Die Linke became the largest opposition party in the Bundestag, office-seeking was not, with the opportunity presented by a potential majority of seats being held by parties on the centre-left in the Bundestag not generating any determination to demand, or enthusiasm for, any coalition building. In the case of Die Linke, this lack of enthusiasm was related to the party's need to safeguard party cohesion, as an overwhelming part of the party was not willing to support a Red-Red-Green (R2G) coalition government at the national level (Lucke, 2015: 5). Commenting on the lessons learned from previous divisions and electoral failures within Die Linke, its former leader Gregor Gysi noted in 2012 that "those who do not like each other have understood that they do need each other" for the electoral survival of the party (Lucke, 2015: 5). It is a fact that without the pragmatic reformers in Eastern Germany as well as the more fundamental oppositional members in the West of the country, Die Linke would not be able to meet the electoral system's minimum $5 \%$ of the vote threshold required to qualify for parliamentary representation. In other words, the party resembles a multi-strategic coalition of different groups on the left that serves the common purpose of safeguarding parliamentary survival and party cohesion.

For this reason, the party decided on a leadership structure that quite successfully offers representation to different wings of the party's spectrum in a dual leadership model, with co-chairing of the party leadership between Gregor Gysi and Oskar Lafontaine; or currently Katja Kipping and Bernd Riexinger, as well as on a parliamentary 
party level between Dietmar Bartsch and Sahra Wagenknecht, having become the norm. However, this structure has come at a strategic price, namely the party is not able to follow a very clear uncontested strategic direction. In fact, it is significant to note that within this model the dominant wings appear to continue to promote their vision of a more engaged coalition role, or the need for a more oppositional positioning, something that was also reflected at Die Linke's June 2017 party congress where the party adapted its programme for the pending September general election, with the co-chair of the parliamentary party, Sahra Wagenknecht, continuing to distance her party from any possible coalition building with the SPD and Greens after the elections (Der Spiegel, 2017).

\section{DIE LINKE AND ITS TENDENCIES AND WINGS: UNITED IN DIVERSITY?}

Inner-party groupings, tendencies and networks are usual features and inner-party plurality can be recognised in everyday party politics. In Germany, there is a long tradition that political parties "officially" sanction and even encourage the formation of inner-party groups that aim at influencing party discourse marked along ideological lines or that represent concerns for single topics (ecology, gay and lesbian). All German mainstream parties recognise these groups within with the help of special procedures that determine their setting up as well as rules and roles that govern their activities. As stressed by Hoff, usually "only a small number" of party activists are associated with wings or groups in regards to the overall party membership base, but "they are important in terms of accentuating and expressing positions that give orientation to ordinary individual party members" (Hoff, 2014: 125-6). These groups are meant to offer special focus or representation relating to issues deemed significant to ultimately advocate and help to develop a more complex party political positioning.

The inner-party groups are also tools to build platforms for inner-party political competition in regard to influence, distribution of resources and to determine the leadership personnel in positions of responsibility and power (Hoff, 2014: 126). And finally, party actors that play key roles and are spokespeople for those groups hold the ability to claim greater legitimacy to argue their policy positions, while being widely recognised as influential on party debates and decisions.

While the effects of inner-party groups described above are common to all political parties in Germany's political spectrum, there are some features that are specific to Die Linke. The party's members and leadership personnel are split into "Fundi" (members representing "fundamental" opposition with a lack of interest in and "resistance" to taking part in coalitions with other parties), and "Realo" (members prepared to advocate toned down "realistic" policy demands to enable coalition building and an embrace of a "transformative" approach by trading in less moderate positions). The graph below, adapted from Hoff (2014: 129), is an attempt to add sophistication and a better understanding to the analysis of the different groups active in Die Linke's 
party-policy-making environment. Here, the various-inner party actors, factions and wings are placed within a vertical axis that differentiates between actors that advocate a more hierarchical political style from those that focus on a more egalitarian style of politics, and within a horizontal axis that distinguishes actors who define their role in terms of putting up political "resistance" from those who belie ve in "transforming" the system (Hoff, 2014: 128-135).

\section{Graph 1.}

Position AND VARIETY OF INNER-PARTY FACTIONS / ACTORS WITHIN DiE LiNKE

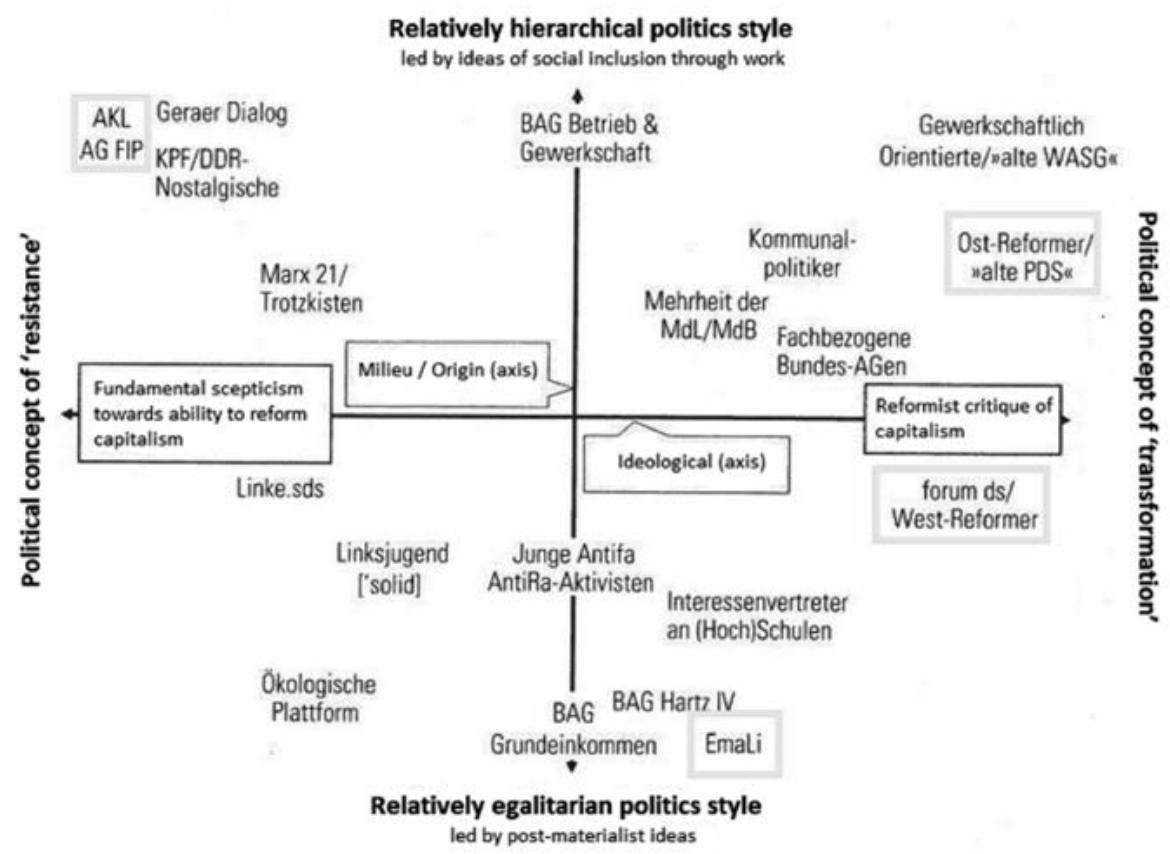

Source: adapted from Hoff, G.-I. (2014) "Die Lage der Flügel und Akteure im politischen Raum der Partei Die Linke", p. 129).

Quite revealing -but not surprising- it is the fact that the large number of functionaries, politicians at the local level, together with the majority of Die Linke party members of the Bundestag and regional Länder parliaments, or practitioners actively engaged in local politics by sitting in councils and regional administrations, as well as those working as trade union representatives (trade unionists, communal politicians, as well as reformers in the East and West) are usually receptive to a far greater degree to compromising on policies when working with representatives from other parties. Regarding inner-party groupings, this group contains many "moderates" who advocate the concept of active policy making engagement and "transformation" and are 
likely to sympathise with the Forum Demokratischer Sozialismus ("forum democratic socialism"-fds)' positions, as it will be shown later.

Hoff (2014) contrasts groups that are most willing to subscribe to engagement and "transformation" with those others that represent and advocate a far more fundamental "scepticism towards the party's ability to reform the capitalist" system, with a strong focus on system analysis and change taking prevalence over day-to-day engagement and aiming towards small-scale piecemeal improvements. In fact, those who advocate more radical and anti-capitalist goals insist on keeping a conscious and distinct distance to the more moderate on the left, namely the SPD and Greens, arguing that the aim to participate in a coalition government means selling out party principles as Die Linke would have to compromise and be likely to be forced to support policies of austerity that should be deemed unacceptable. Those on the opposing part of the inner-party policy continuum represent therefore a more fundamental call for resistance towards the prevalent political and economic system.

On this side of the spectrum one finds more ideologically driven groups, including the "Antikapitalistische Linke" (anti-capitalist left-AKL) or "Die Linke. Sozialistisch-demokratischer Studierendenverband" (socialist-democratic students" associalition-Die Linke.SDS). Somewhere between those opposites we can locate the influential broadly pro-Keynesian and trade unionist "Sozialistische Linke" (Socialist Left-SL) as well as the liberalist new-social movement "Emanzipatorische Linke" (emancipatory left-EMA.LI) group representing the other large and key inner-party tendencies within Die Linke that we will briefly look at.

Significantly, the various factions and inner-party currents within Die Linke have not developed accidentally, but are an important and intended part of the party's structural make-up. In fact, the party's constitution explicitly encourages the set up and official recognition (Innerparteilicher Zusammenschluss-Bundessatzung \$7) of such groups by clearly determining how they may compete to influence the party's priorities, debates and programme (fds, 2015). The party itself describes the role of such groups as twofold: firstly, they are supposed to influence inner-party discourse and its quality, and secondly groups can enhance their members" ability to join party bodies as well as win places on parliamentary lists and representation in parliament (Die Linke NRW, 2015). Officially recognised and most influential are the previously mentioned Anti-Capitalist Left-AKL; Emanzipatorische Linke-Ema.Li (Emancipated Left); Socialist Left-SL and the Forum Demokratischer Sozialismus-fds (Forum Democratic Socialists); but others include the more ideological system-sceptic "Geraer/Sozialistischer Dialog (Gera, a city in Thuringia/Socialist Dialogue); Kommunistische Plattform (Communist Platform-KPF); and the Marxistische Forum (Marxist Forum). Most of these inner-party groups were launched or re-launched when Die Linke officially reconstituted itself in 2007, concluding the merger of the West German WASG and predominantly East German Linkspartei/PDS. In other words, many of them have been established for a substantial amount of time, are well organised and possess effective instruments or publications to share their points and debates across the party spectrum. 
In order to assess the ability of Die Linke to offer a consistent message, we need to briefly locate the different key tendencies or "inner party pressure groups" within the party's inner-political spectrum (Ema.Li, 2007). More broadly, the key tendencies consist of a manageable number. As it can be rightly expected, the wings' general ideological and strategic positioning clearly influences and reflects their analysis and advocated policies when they deal with specific policy areas, as the example of the policies on the Euro and Financial Crisis will show. Similarly, when accounting for the diversity of the various factions and inner-party currents within Die Linke, it comes as no surprise that agreeing on the dismissal of policy positions by party competitors poses a far easier task than the cross-factional inner-party agreements of "far from ideal" compromise formulas (particularly on national level policies) which would be required when being forced to embrace cooperation on policies with other potential party allies on the centre-left. In order to back up this point and to get a better understanding of the varying attitudes towards "left of centre" policy cooperation (with the SPD and Greens) and the diversity of groups and traditions that are part and parcel of Die Linke, a short introduction to the key tendencies is helpful.

\section{Forum Demokratischer Sozialismus (fds)}

The "Forum Demokratischer Sozialismus" (fds) represents the "social democratic", "reformist" and "realo" spectrum of Die Linke which advocates much of the more moderate policy approaches of the pre-2007 "Eastern" (Linkspartei) PDS (fds, 2007). The fds represents "social democracy" and the members of this group define themselves as "democratic socialists" with the aim to "change society" by seeking inclusive popular "stable and lasting majorities" (fds, 2007). In fact, its founding declaration stresses the need to "dream up a sensible good socialist system that would put no one off', with this wing determined to engage by advocating the party's openness to join coalition governments (fds, 2007). While critical about numerous policy positions held by the SPD, this tendency strongly advocates the intensification of the debate between the SPD, Greens and Die Linke to create an electoral centre-left alternative for the 2017 general election (Korte and Heilig, 2015). The widely discussed "Aprilthesen", a list of eleven propositions devised and co-authored by the party's deputy chair and finance policy specialist Axel Troost, encourage and contribute to the party's debate over its future strategy by stating "where the party has (currently) positioned itself" and where it "should" programmatically "move to" before the general elections of 2017 (Recht et al., 2015: 7).

Similarly, the paper argues for the need to aim at "government responsibility" by stressing that "a change of government will not be possible without the SPD and Greens" and that "this means that the Die Linke needs to compromise and relinquish some of its positions" and pre-conditions (Recht et al., 2015: 7). Consequently, the fds wing of the party is frequently depicted as representing moderate and pre-thirdway traditional reformist social democratic positions. 


\section{Sozialistische Linke (SL)}

Similar to the Forum Sozialistische Linke (fsl), the "Sozialistische Linke" (SL) defines itself as a moderate representative of that social democratic tradition, however not without stressing that besides "realism" it also represents a "radical" perspective (SL, 2007). This group is sometimes referred to as "Mittelerde", the centre ground, in regards to the group's location within the spectrum of the party. In contrast to the fsl, the SL stresses its particularly strong link to Germany's trade union movement. It is also fair to say that the majority of its members are former sympathisers of the WASG and from West Germany with Oskar Lafontaine being one its key initiators.

The SL's agenda appears to be to the left of the fsl as it not only stresses the "need for a revival of public ownership, public investment, a strong welfare state and a socio-ecological restructuring attempt for the economy", but also includes the "rejection of the current EU treaties" linked to the "demand for a new beginning to the EU", with the SL's ultimate aims remaining the "overthrowing of capitalism" in a self-proclaimed "realistic and radical" manner (SL, 2007). The fds frequently competes with the SL for the nomination spots of parliamentary candidates, having complained in the past that some of its representatives had lost out in a concerted effort against candidates from the fds, for instance, during the party's nominations of candidates for the 2014 European Parliament election, with the final list lacking "sufficient representation" of "left-wing" as well as "western"-based candidates (SL, 2014a). In any case, the SL supported re-election of the party's moderate "competent" co-leaders Bernd Riexinger and Katja Kipping in 2014 as well as the fsl-linked party deputy and finance policy specialist Axel Troost (SL, 2014b).

This party wing is frequently depicted as representing the "new" part of the party (after its merger and re-foundation in 2007) as most of the SL's founding members came from the "West" German trade union movement and WASG. However, the SL also encompasses members from a more "Trotskyite" group called "marx 21 " that has had some effect on the programmatic positioning of the SL and represents a more system-sceptic approach by opposing, for example, those party members that are sympathetic towards embracing participation in coalition governments (Marx21, 2015).

\section{Emanzipatorische Linke (Ema.Li)}

The "Emancipatory Left" advocates a "liberal" approach to society and promotes ideas of "radical democratic emancipatory" nature with the aim of serving as an "inclusive discussion forum within as well as outside the party" to assist the development of a "new left" (Ema.Li, 2015). "Freedom and socialism" are viewed as not mutually exclusive, but instead complementary and related to one another (Bonk et al., 2006). The Ema.Li grouping stressed in its early documents its ability to attract supporters from the East and West, while being a political tendency that is not "exclusive", but instead actively encourages members from other wings and 
tendencies to join in, and here in particular those from the fsd and SL, Ema.Li states as one of its overarching aims to overcome the "hardened fronts between the various inner-party wings to facilitate a positive discourse" (Ema.Li, 2015). Similarly, the group's founding document calls for an end to the "outdated conflict" between "realos" and "fundis" and wishes to act as a bridge between both groups. Judging from the group's webpage, members from Ema.Li appear to be particularly interested in debates surrounding the changing world of work and advocate, for example, the idea to create an unconditional basic income (Bonk et al., 2006). The most prominent member of Ema.Li, emphasising the bridging character of this group, is Die Linke's current party leader Katja Kipping.

\section{Antikapitalistische Linke (AKL)}

On the more radical inner-party spectrum to the left stands the "anti-capitalist left" that advocates a more fundamentalist opposition role rejecting participation of Die Linke in any coalition government (AKL, 2013). The AKL describes itself as a group within Die Linke that wants to strengthen the "anti-capitalist" profile of the party. The group is also open to non-party membership as it aims to link the party with movements that are active outside of parliament $(i d$.). The AKL advocates that Die Linke should play the role of "credible opposition force" as it cannot see a credible electoral "left-of-centre majority" cooperating with the SPD and Greens. Instead, the group argues that such cooperation is "illusory wishful thinking" as being part of such a coalition would only be for the reason of gaining power while having to pay for this the unacceptable price of "supporting austerity" and "acting in the interests of German capital” (AKL, 2014: 27).

For that reason, the AKL has identified numerous red lines ("non-negotiable positions") that would have to be met by the SPD and Greens before the group could support being part of any government coalition. In the matter of the Euro crisis, these include, for example, a rejection of both the "fiscal compact" and the "Troika's bailout conditions" as well as "any bank rescue plans". In addition, the AKL insists that that there cannot be any German military involvement abroad, demands an end to privatisation, rejects social cuts, and demands an end to the use of nuclear and coal power $(i d$.$) . Clearly, the attitude towards any cooperation with other parties on the$ left as part of a coalition stands in stark contrast to the beliefs and strategies advocated by the fds.

Not to be left out, another larger and recognised inner-party group on the left that must be mentioned is called the Communist Platform (Kommunistische Plattform$\mathrm{KPF}$ ). This group is composed of "communists" who aim to "preserve and develop Marxist ideas" within the party (Die Linke, 2011). One of its previous prominent members has been Sahra Wagenknecht whose active membership was put on hold when she became a member of the party's executive in 2010. In fact, it is generally accepted that party members who accept key party positions suspend their activities 
within tendencies in order to be able to reach out to the wider party when carrying out leadership responsibilities.

The "Communist Platform" has not been particularly engaged with the details of the Euro crisis as its members reject outright the wider workings of the current economic system, and for that reason are generally more engaged in focusing on broader ideological debates. For that reason, while mentioned, the activities of that wing will not be considered any further in this article. Similarly, there are numerous other smaller wings and tendencies, many of which are mentioned in Hoffs table of positions of inner-party factions and actors within Die Linke, but which do not require further mention for the purposes of this paper (Hoff, 2014: 129). In fact, numerous smaller groups such as the AKL or "Geraer Dialog/Sozialistischer Dialog" hold more of a fringe status and have complained in the past that their policy documents are frequently blocked at party conventions and not permitted to proceed to the party's programmatic negotiation stages (Sozialismus, 2015).

What remains clear from the analysis above is the fact that Die Linke contains a large spectrum of left tendencies that are mostly located well beyond the centre-left policy ideas of the SPD and Greens. Differences in the perceived role of Die Linke either as part of a transformative coalition of progressive parties on the left or instead as an actor to resist engagement and protest against the convention of the established political and economic conventions are to be expected to a certain degree. In the same way the party's groups reflect the wider left spectrum between "ideas of economic growth" and "social inclusion through work" as well as more "post-materialist" and environmental concerns. This brings us back to our starting point: that Die Linke itself represents a coalition of different more or less radical left wing political belief systems and strategies for change, with many ideological divisions going much further back than the re-foundation of Die Linke in 2007. In fact, groups often represent conflicts and ideological divisions among left ideologies that reach back to the early $20^{\text {th }}$ century. Or in the words of Benjamin-Immanuel Hoff, disagreements reassemble the disagreements and political "evergreens” of Germany's wider Left (Hoff, 2014: 134).

\section{DIE LINKE AND THE EURO-CRISIS}

After the brief review of the wide spectrum of left- and radical left- policy approaches represented within the party, it is helpful to gain some understanding of the differing views about the crisis among the party's leadership personnel as well as how the party's policies are expressed in its programme.

Contrasting Dr Axel Troost's and Dr Sahra Wagenknecht's attitudes on this matter gives a good example as both are prominent finance policy experts within the party who have published widely on the financial and euro crisis in the form of books, articles, and policy programmes. Moreover, Sahra Wagenknecht has receiving a great deal of attention due to her frequent appearances on German prime time TV politics talk 
shows. Both politicians somehow embody the difference between the party's more moderate Eastern wing and the more Western sceptic policy one, commonly represented by the party's regional party associations. Axel Troost comes originally from pre-unification West Germany and represents more moderate social democratic policy convictions, which has allowed him to win his nomination on a moderate regional East German party list from Saxony in the East, while the East German Sahra Wagenknecht, who is commonly associated with the more radical wing of the party, has been given her parliamentary mandate by a West German party association from North Rhine-Westphalia that is generally deemed to be part of the more radical side of the party's political spectrum.

It is also important to emphasise that Axel Troost has in the past stressed that the differences in opinion between Die Linke's different wings are a common and necessary part of inner-party democracy that aids the fleshing out of official policy programmatic positions. In fact, Troost goes as far as insisting that the degree of disagreements to be found in Die Linke are in line with internal divisions also found in other German parties. He argues that the differences in the analysis and agreements of the causes of policy challenges, such as those arising from the financial and euro crisis, are surprisingly similar amongst the different groups represented in Die Linke, while the most fundamental disagreements among them have to do with the strategic direction and the most suitable policy solutions to deal with identified policy challenges (Troost, 2015a). This would mean that Troost and Wagenknecht may advocate substantially different strategies on how to deal with the financial and euro crisis, but they would share an understanding of the structural issues and flaws of the Economic and Monetary Union system as well as their analysis of the role of the German government within it. Their agreement is apparent in the party's programmatic compromises on the issue, as summed up well in the 2013 general election programme "100\% Sozial" (Die Linke, 2013).

In the run-up to the September 2013 election, the Euro crisis was perceived in Germany to have reached its height; they reason why Die Linke invested a great deal in covering the issue in the party's manifesto. As a result, the programme offers a good and detailed overview of Die Linke's broader understanding of the crisis and how it should be dealt with. The 100-page-strong election manifesto made some very strong points about blaming the crisis on the EMU's systemic economic imbalances, but explicitly turned it into a more general critique of the capitalist system (Münchau, 2013). The party stressed its understanding that it "wasn't excessive expenditure by some Eurozone member states that had been causing Europe's crises, but "a triad of redistribution of wealth to the top, deregulation as well as privatisation" that should be blamed for being "largely responsible for the financial and economic crisis" (Die Linke, 2013: 46).

In addition, the programme accused Angela Merkel's government of having attempted to "[...] reinterpret the financial crisis as a sovereign debt crisis" and thereby "confusing cause with effect" (ibid:: 46). Furthermore, the manifesto reproached the Merkel government for having blamed the crisis on the countries that were suffering 
most under the debt and thereby distracting from what the party views as the "real causes" of the crisis, namely the facilitation of bank bailouts. The latter were viewed not only as responsible for the unsustainably high sovereign debt levels of some countries but also as part of a system that had been ultimately rigged to benefit German banks (ibid.: 47). This interpretation of the crisis indicates a clear conviction regarding a strong crisis narrative that could clearly be agreed upon by the different groups present within Die Linke. And as a result, this was reflected by Die Linke's voting patterns on legislation in the Bundestag, where Die Linke's representatives consistently rejected and voted against measures put forward by the government on issues such as the "European Stability Mechanism", the "Fiscal Compact" and bailout packages as tools of crisis management (ibid.: 46).

Appearing certain about its macroeconomic analysis of the crisis, the party pledged considerably radical solutions entrenched in the party's ideological underpinnings (Münchau, 2013). In fact, Die Linke advocated a "European one-off tax on the wealthy to reduce current state debt levels"; "a new tax for top earners" (75\% on income above $€ 1$ million annually); "steps to tackle tax evasion"; "the nationalisation of large private banks"; and envisaged (admittedly "for a short term and within a framework") that the European Central Bank should be given the role of directly financing member states struggling with their deficits (ibid.: 48). Having said this, the programme has been criticised for falling short on accounting for the need to increase international policy coordination with Die Linke, focusing instead its policy prescriptions predominantly on questions of redistribution of wealth at national level (Münchau, 2013).

As for the European Union integration, the programme states the party's demand for a "re-foundation of the European Union", which is criticised for having become neo-liberal in orientation since the Maastricht Treaty. And while the programme clearly states that "EMU is being viewed as containing huge errors in its current setup", Die Linke did stress that it did "not want an end to the Euro" (Die Linke, 2013: 49). Above all, it remains clear that despite substantial disagreements between the different tendencies within the party on how to engage with the political system, there is a substantial agreement within Die Linke on the interpretation of the causes of the crisis.

Similarly, disagreements in discourse among the different Die Linke factions did not always or necessarily translated into votes. For example, Sahra Wagenknecht had been arguing that reform of the "Eurozone-dominated neo-liberal austerity mainstream" wasn't currently possible (Troost, 2015b), in contrast to Axel Troost who had insisted that "disengagement" to actively influence the struggle for sensible reforms would only make it easier for neo-liberal decision-makers to adopt in an unopposed manner fatally wrong policies with massive negative consequences (Troost, 2015a). Yet, when voting on government legislation introduced and debated in the Bundestag dealing with the Financial- and Euro crisis, Wagenknecht's and Troost's records show far greater agreement than those shared with the other two "centre-left" parties in parliament. 
Using the example of key "roll-call" votes on the Euro mechanisms and bailouts, Die Linke's MPs -from all the different wings of the party (fds, SL \& Ema.Li)- have thus consistently voted together (see table 2). While this should be expected, considering that Die Linke MPs were voting on legislation proposed by a Christian Democrat-led government and playing its role as an opposition party on the left, what may be even more revealing is the way Die Linke's MPs voted distinctly differently to its potential partners on the centre-left, the SPD and Greens. Die Linke voted alongside the SPD only 2 out of 14 times, and together with the Greens only 5 times out of 14 . In contrast, the Greens voted alongside the SPD at least 10 out of 14 times (Bundestag, 2016). This speaks volumes of the slight likelihood of future cooperation between the three parties.

This indicates that, while Die Linke may appear divided and it is composed of a substantial group of differing wings that hold distinctive ideological policy principles (also see graph 12 ), Die Linke's parliamentary party has acted and voted with exceptional unity in the Bundestag in terms of policy issues and understandings related to the crisis and debated in the Bundestag. This shows that, in the case of the Euro crisis, Die Linke's policy output has been surprisingly consistent, despite its different wings and ongoing inner-party debates. However, it must be stated that the party voted consistently against the government with such votes lending themselves to do so, with the anti-systemic positions certainly partly explaining such a degree of party unity. However, a more strategic and coordinated approach with the other two parties on the centre-left, SPD and Greens, would have been possible so to close ranks and invest in the possibility of future cooperation. But this option was clearly not embraced. 


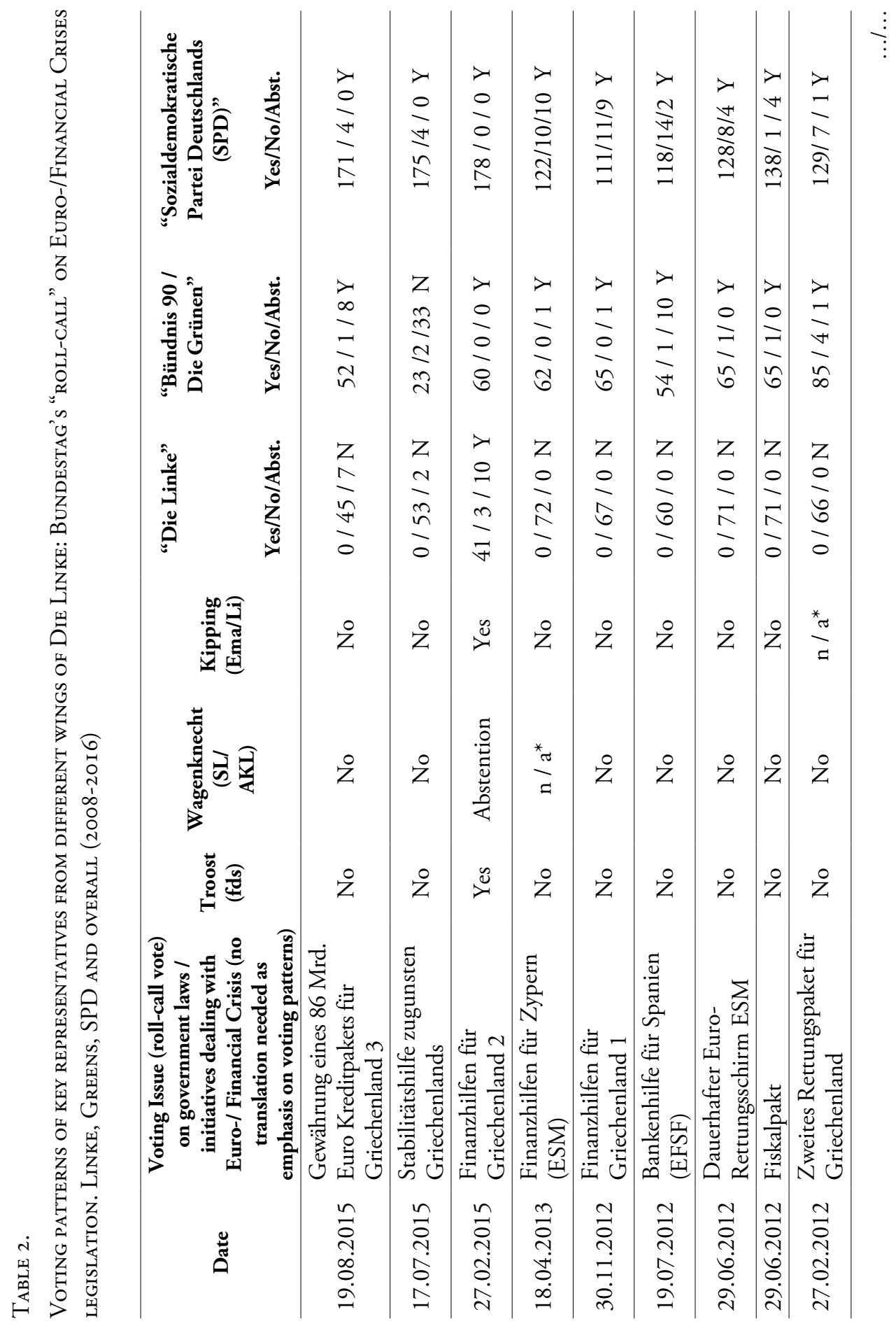




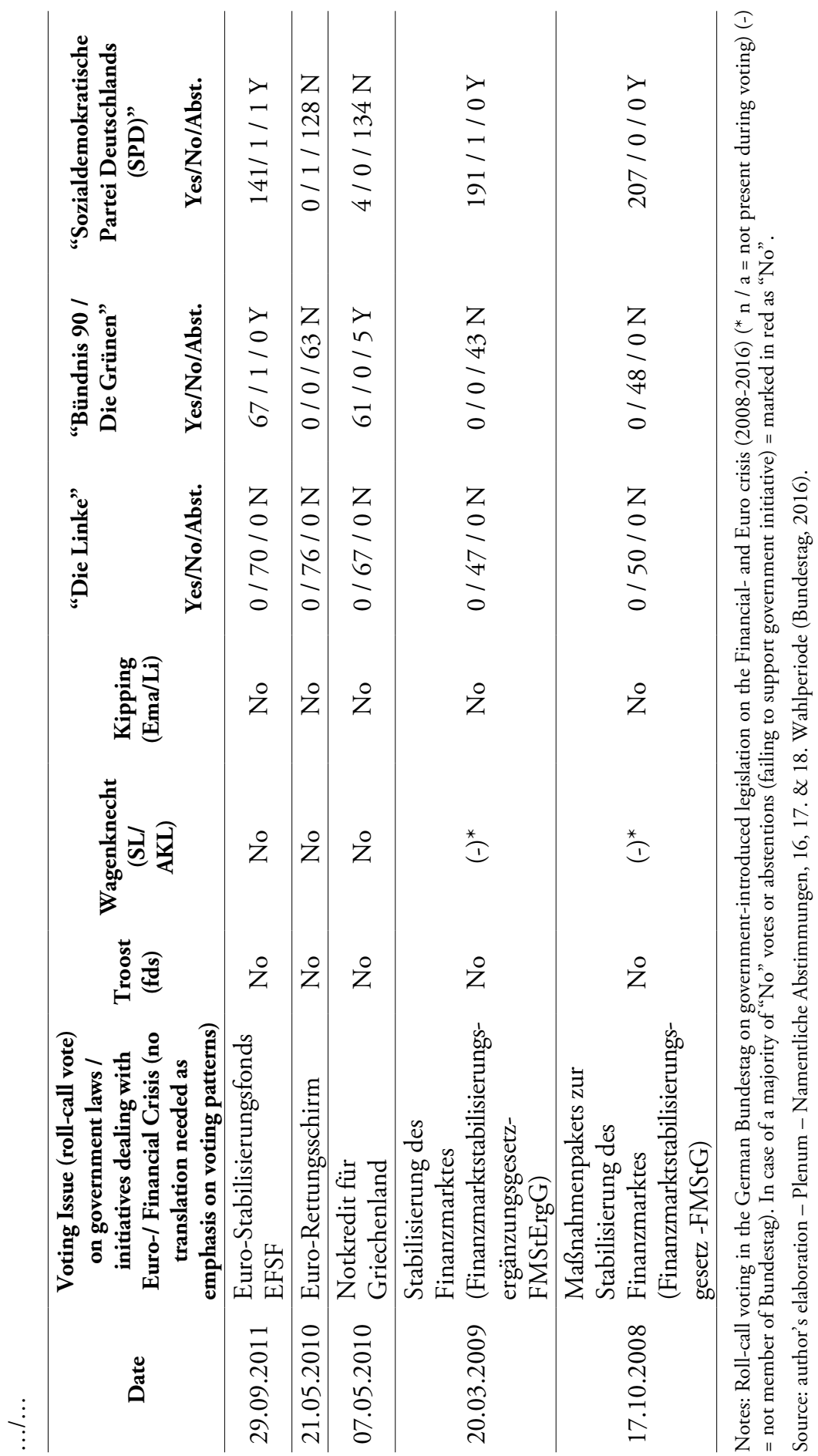




\section{Conclusion}

Judging by the evidence of Die Linke's diverse composition and need for party cohesion, we can conclude that the party is being constrained from more enthusiastically and strategically embracing an "office-seeking" "left-of-centre" cooperation with the SPD and the Greens at the national level. Thus, in spite of the fact that only a successful cooperation between the three parties could challenge Germany's centre-right government majority, there are two good reasons why this cooperation has not yet materialised.

Firstly, there is the unwillingness to cooperate with, and even dismissal of, Die Linke by the SPD and Greens, that refuse to embrace Die Linke as a possible partner for strategic as well as programmatic reasons (Stern, 2005; Höll, 2012; Tagesspiegel, 2016). Secondly, and as it has been shown in this article, there is also evidence that some of the reasons for Die Linke acting as a "missing link" within the wider German left-of-centre are homemade and lie within the party's structural requirements that has forced Die Linke to prioritise safeguarding party cohesion by avoiding the risk of undermining the delicate balance that has been struck between its different factions, that any advanced cooperation agreements with the SPD and Greens would necessarily pose. In fact, by "seeking office", Die Linke would be bound to alienate some of its diverse membership coalition when the party were inevitably forced to embrace substantial policy compromise in order to be able to agree on some common policy positions with the SPD and Greens.

Die Linke's composition of programmatically and ideologically highly diverse groups which represents a wide ideological continuum reaching from social democrats (fds and SL) to anti-system groups opposed to capitalism (AKL and KPF) means that Die Linke's balance of factions needs to be partly sustained. Therefore, keeping this "coalition" of factions is an implicit precondition for safeguarding the survival of the party; and this can only be achieved by mobilising sufficient numbers of activists as well as a critical mass of voters to keep Die Linke politically relevant by attracting sufficient electoral support to reach the $5 \%$ minimum threshold that is required to win parliamentary representation in Germany. In other words, Die Linke's restrictive policy choices of avoiding cross-party cooperation with the SPD and Greens, something that remains highly contested internally, may well be of existential importance to the party, as it aims to preserve cohesion and essentially prioritises the very party survival. For this reason, Die Linke has been understandably hesitant to commit itself to any "centre-left" coalition building with all the consequences that this would entail in the face of having to substantially compromise on policy positions with the far more moderate centre-left SPD and Greens. For example, in the case of the positions adopted and expressed during Bundestag voting on the crisis, Die Linke could not have sustained such a degree of policy rejection, but instead would have had to display substantial willingness to engage and compromise, even more so, if it had had to play a part in any centre-left coalition government. 
However, calling Die Linke a "missing link" on the left would be unfair, as this would indicate that the party has failed to engage in policy debates and position itself. This has clearly not been the case, particularly when looking at the sheer volume of work, programmes and publications through which party members and supporters have contributed to the debate on the crisis from all sides of the party's political spectrum. In addition to the party's engagement in the Bundestag (Spiegel, 2015a), Die Linke's think tank -the Rosa-Luxemburg Foundation (RLS)- has lent itself since 2008 as a repository made of more than 110 studies that broadly deal with the crisis (Candeias, 2010). This shows that Die Linke contains real scale in terms of membership, electoral support, financial resources as well as programmatic thinking.

If Die Linke should, one day, decide to become part of a wider German government to the left (SPD and Greens being willing, as well as electoral majorities and interparty discourse permitting), international interest can be expected to surge in the party's policy debates. Instead of representing a missing link, Die Linke continues to hold the potential to ultimately transform itself into a coalition partner, if leading members decide "in favour of moving towards the option of taking on government responsibility" (Lucke, 2015: 8) and the various party factions start believing that their party could make a real difference as a result of Die Linke being able to implement sufficient amounts of their policy ideas as part of a national level centre-left coalition with the SPD and Greens.

\section{References}

Antikapitalistische Linke-AKL. 2013. Über die AKL. Available at: http://www.antikapitalistische-linke.de/?page_id=40.

Antikapitalistische Linke-AKL. 2014. "Kapitalismus bedeutet Krieg, Umweltzerstörung und Armut!", Berlin: AKL-Broschüre-2014. Available at:

http://www.antikapitalistische-linke.de/wp-content/uploads/2014/02/AKLBrosch \%C3 \%BCre-2014.pdf.

Bundestag. 2016. Plenum-Abstimmungen. Available at:

http://www.bundestag.de/bundestag/plenum/abstimmung/16wp (16. Wahlperiode). http://www.bundestag.de/bundestag/plenum/abstimmung/grafik (17. \& 18. Wahlperiode).

Bonk, Julia, Katja Kipping and Caren Lay. 2006. "Freiheit und Sozialismus. Let's make it real: Emanzipatorische Denkanstöße für die neue linke Partei", Ema.Li, April 2006. Available at: https://emanzipatorischelinke.files.wordpress.com/2013/01/ freiheit-und-sozialismus-lets-make-it-real.pdf.

Bouma, Amieke. 2016. "Ideological Confirmation and Party Consolidation", in Luke March and Daniel Keith (eds.), Europe's Radical Left: From Marginality to the Mainstream (pp. 133-154). London: Rowan and Littlefield. 
Candeias, Mario. 2010. „Ein fragwürdiger Weltmeister: Deutschland exportiert Arbeitslosigkeit", Reihe Standpunkte, Juni 14/ 2010. Available at:

http://www.rosalux.de/fileadmin/rls_uploads/pdfs/Standpunkte/Standpunkte_ 14-2010.pdf.

Chiocchetti, Paolo. 2017. The Radical Left Party Family in Western Europe, 19892015. Abingdon: Routledge.

Der Spiegel. 2015. „Datenlese: Opposition im Bundestag Wir hätten da mal 1313 Fragen“, Hamburg, Der Spiegel-Online, 4-23-2015. Available at: http://www. spiegel.de/politik/deutschland/bundestag-so-arbeiten-die-gruenen-und-die-linken-a-1026871.html.

Der Spiegel. 2017. „Linken-Parteitag geht auf Distanz zu SPD und Grünen“, Hamburg, Der Spiegel-Online, 6-11-2017. Available at: http://www.spiegel.de/politik/ deutschland/linke-sahra-wagenknecht-geht-auf-distanz-zu-spd-und-gruenen-a-1151594.html.

Die Linke. 2011. "Kommunistische Plattform der Partei Die Linke“. Available at: https://www. die-linke.de/partei/zusammenschluesse/kommunistische_plattform_der_partei_ die_linkel.

Die Linke. 2013. "100\% Sozial”, Wahlprogramm zur Bundestagswahl 2013. Berlin: Die Linke.

Die Linke NRW. 2015. “Politische Strömungen”. Available at: http://www.dielinke-nrw.de/nc/partei/arbeitskreise/politische_stroemungen/.

Emanzipatorische Linke/Ema.Li. 2015. “Über Ema.Li”. Available at: https://emanzipatorischelinke.wordpress.com/uber-uns/

Forum Demokratischer Sozialismus-fds. 2007. "Gründungserklärung: Also träumen wir mit hellwacher Vernunft: Stell dir vor, es ist Sozialismus, und keiner geht weg!" Initiative für den Demokratischen Sozialismus in der neuen Partei DIE LINKE. Available at: http://forum-ds.de/?page_id=351.

Forum Demokratischer Sozialismus-fds. 2015. "Erklärung zum Strömungsratschlag vom 12. Juni 2015 in Berlin - Gemeinsame Erklärung der Teilnehmenden des Forum Demokratischer Sozialismus (fds), der Sozialistischen Linken (SL) und der Emanzipatorischen Linken (Ema.Li)”. Available at: http://forum-ds.de/wp-content/ uploads/2015/06/Erkl \%C3 \%A4rung-zum-Str \%C3 \%B6mungsratschlag.pdf.

Gathmann, Florian. 2016. "Großes Treffen von SPD, Linken und Grünen: Bisschen schnuppern, bisschen stänkern”, Der Spiegel-Online, 10-16-2016.

Available at: http://www.spiegel.de/politik/deutschland/grosses-rot-rot-gruen-treffen-r2g-in-berlin-a-1116976.html.

Holmes, Michael and Knut Roder. 2012. The Left and the European Constitution. Manchester: Manchester University Press.

Hoff, Benjamin-Immanuel. 2014. Die Linke: Partei neuen Typs? Hamburg: VSA-Verlag

Höll, Susanne. 2012. „Koalitionsaussage für Bundestagswahl 2013 SPD-Chef Gabriel schließt Bündnis mit Linken“, Süddeutsche Zeitung, 1-25-Januar 2012. Available at: http://www.sueddeutsche.de/politik/koalitionsaussage-fuer-bundestagswahlspd-chef-gabriel-schliesst-buendnis-mit-linken-aus-1.1266407. 
Korte, Jan and Dominic Heilig. 2015. "Im freien Fall”, die Tageszeitung, 7-7-2015. Available at: http://taz.de/fileadmin/static/pdf/Linke-und-Gruene-Paper.pdf.

Lucke, Albrecht von. 2015. "Einheit in der Spaltung: Die Linkspartei nach Gysi". Berlin: Blätter für deutsche und internationale Politik, 7 / 2015: 5-8

Marx21. 2015. "Bielefelder Parteitag: Klare Kante statt trüber Brühe", Marx21, 6-92015.Availableat:http://marx21.de/bielefelder-parteitag-klare-kante-statt-trueberbruehe/.

March, Luke and Daniel Keith (eds). 2016. Europe's Radical Left: From Marginality to the Mainstream? London: Rowman and Littlefield International.

Münchau, Wolfgang. 2013. "Rot-Rot-Grün ist die beste Lösung für Europa“, Spiegel-Online, 8-28-2013. Available at: http://www.spiegel.de/wirtschaft/soziales/ wolfgang-muenchau-ueber-das-wahlprogramm-der-linken-a-919067.html.

Recht, Alexander, Paul Schäfer, Axel Troost and Alban Werner. 2015. "Aprilthesen”, Sozialismus extra, 32. Available at: http://www.sozialismus.de/fileadmin/users/ sozialismus/pdf/Sozialismus_extra_2015-06_Web.pdf.

Sozialistische Linke-SL. 2007. Gründungserklärung: Realistisch und Radikal. Available at: http://www.sozialistische-linke.de/ueber-uns.

Sozialistische Linke-SL. 2014a. "Nach dem Europaparteitag-DIE LINKE kämpft für ein anderes Europa", Stellungnahme des BundessprecherInnenrates, 2-23-2014. Available at: http://www.sozialistische-linke.de/politik/debatte/969-bsr-nach-ept.

Sozialistische Linke-SL. 2014b. "Die SL zum Berliner Parteitag der LINKEN", Stellungnahme des BundessprecherInnenrates, 5-15-2014. Available at: http://www. sozialistische-linke.de/politik/debatte/992-sl-bpt-berlin-2014.

Sozialismus Info. 2015. "Gysis 'Vermächtnis' und die Zukunft der Linken”, Sozialistische Alternative (SAV), 10. Available at: https://www.sozialismus.info/2015/06/ gysis-vermaechtnis-und-die-zukunft-der-linken/.

Steenbergen, Marco R. and David J. Scott. 2004. Contesting Europe? The salience of European integration as a party issue, in G. Marks, G. and M. G. Steenbergen, European Integration and Political Conflict. Cambridge University Press. Disponible en: https://doi.org/10.1017/CBO9780511492013.010.

Stern. 2005. „Rot-rot-grüne Gedankenspiele: Überflüssig wie ein Kropf», Stern-Online, 2. August 2005. Available at: http://www.stern.de/politik/deutschland/rotrot-gruene-gedankenspiele--ueberfluessig-wie-ein-kropf--3300542.html.

Tagesspiegel. 2016. „Bundestagswahl 2017: SPD und Linke loten Bedingungen für Rot-Rot-Grün aus", Der Tagesspiegel, 7-10-2016. Available at: http://www. tagesspiegel.de/politik/bundestagswahl-2017-spd-und-linke-loten-bedingungenfuer-rot-rot-gruen-aus/ 13854638 .html.

Troost, Axel. 2015a. Authors' interview with Dr Axel Troost. Leipzig.

Troost, Axel. 2015b. "Raus aus dem Euro?", Die Linke, 8-25-2015. Available at: http://www.die-linke.de/nc/die-linke/nachrichten/detail/zurueck/nachrichten/ artikel/raus-aus-dem-euro/. 
Presentado para evaluación: 14 de noviembre de 2016.

Aceptado para publicación: 30 de octubre de 2017.

\section{KNUT RODER}

K.Roder@shu.ac.uk

Senior Lecturer and BA Politics Course Leader at Sheffield Hallam University. He has published on the politics and political economy of European integration, party politics with a focus on Germany and the UK. And he is the author of Social Democracy and Labour Market Policy (2003); and co-editor (with Holmes, M.) of The Left and the European Constitution (2012) and The European Left and the Crisis (forthcoming 2018). 